\title{
PERKEMBANGAN PARTI DAN KESEDARAN POLITIK DI PASIR MAS, KELANTAN SEBELUM MERDEKA
}

\author{
Ahmad Izahan bin Ibrahim \\ Mohammad Redzuan Othman
}

\begin{abstract}
Pasir Mas is one of the largest districts in the state of Kelantan and has considerable influence on the overall Kelantan political environment. In every Malaysian general election, Pasir Mas paliamentary and state seats were among the hot seats contested between the two biggest Malay-based political parties, UMNO and PAS. Both parties had almost equal strength in Pasir Mas in term of influence and support. This article analyses the origins of political consciousness in Kelantan before the Second World War and before the Malayan independence in 1957. The history on the establishment and the development of both parties in Pasir Mas is also elaborated. In the early stage, UMNO was led by the Malay aristocrats, while PAS by the religious leaders. The discussion in the article also discussed on how UMNO and PAS competed with each other in the first federal election in 1955. The result of the election clearly showed that the people of Pasir Mas gave their undisputed support to UMNO/Alliance as a prelude to the achievement of independence from the colonial rule.
\end{abstract}

\section{Pendahuluan}

Kesedaran berpersatuan dan berpolitik tercetus dan berkembang di Pasir Mas bermula sejak awal abad ke-20 lagi. Kemunculan kelab dan 
persatuan yang berbeza orientasi sama ada memperjuangkan bahasa, kebudayaan dan sosial telah mencorakkan keinginan penduduk untuk berpolitik dan menentang penjajahan Inggeris. Kesedaran berpolitik ini telah dikembangkan kepada masyarakat setempat melalui penerbitan akhbar dan majalah yang diusahakan oleh kelab serta persatuan yang diwujudkan pada waktu itu.

Kemunculan sentimen anti-penjajah menjadi semakin kuat dengan cadangan Malayan Union oleh penjajah British. Sentimen ini mendorong kepada muafakat terbesar orang Melayu yang membawa kepada penubuhan United Malays National Organisation (UMNO) oleh kelab dan persatuan yang wujud di Tanah Melayu ketika itu. Persatuan Melayu Kelantan dan Persatuan Persetiaan Melayu Kelantan turut bergabung dalam gabungan UMNO menentang Malayan Union di Kelantan. Pemuafakatan ini meyakinkan UMNO bahawa kesatuan yang wujud dalam kalangan orang Melayu ini mampu memberikan tekanan kepada penjajah untuk memberikan kemerdekaan tanpa berlaku pertumpahan darah. Terbukti bahawa pemuafakatan yang pada mulanya berlaku sebagai protes kemudiannya berjaya membawa kepada kemerdekaan Tanah Melayu pada 31 Ogos 1957.

Penubuhan dan perjuangan UMNO ternyata tidak dapat memenuhi aspirasi sebahagian orang Melayu yang inginkan identiti Islam yang lebih jelas dalam mengisi hala tuju Tanah Melayu yang merdeka. Walaupun dalam UMNO terdapat sayap yang dianggotai oleh kelompok berpendidikan agama, namun ramai dalam kalangan mereka yang tidak berpuas hati dengan dasar-dasar UMNO yang dianggap bertentangan dengan Islam dan tidak memenuhi aspirasi orang Melayu. Kemuncak rasa tidak puas hati ini menyebabkan golongan ini keluar dari sayap agama UMNO dan menubuhkan kumpulan baru yang membawa kepada kelahiran Parti Islam SeMalaya (PAS).

Kelantan yang majoriti penduduknya orang Melayu merupakan negeri yang menjadi sasaran UMNO dan PAS bagi meluaskan pengaruh masing-masing. Pasir Mas pula merupakan sebuah daerah di negeri Kelantan yang terletak tidak jauh dari Kota Bharu yang terkenal dengan tradisi keilmuan dan keinteletualan di negeri Kelantan. Pasir Mas juga terkenal dengan peranan ulamanya dan pendidikan pondok yang menjadi tapak yang subur kepada perkembangan PAS. Dari sini PAS berkembang dan melebarkan sayapnya di seluruh negeri Kelantan. Walaupun bermula di Pasir Mas dan mendapat sambutan baik, namun parti tersebut tidak berjaya membuktikan pengaruhnya dalam Pilihan Raya Persekututan Pertama 1955 di kawasan tersebut. Ini bukan disebabkan penolakan pengundi terhadap kehadirannya, tetapi lebih kepada keinginan memberikan mandat besar kepada UMNO atau 
Perikatan bagi membolehkan Tanah Melayu mencapai kemerdekaan dari British.

\section{Kesedaran Politik Awal di Kelantan}

Kesedaran berpolitik dalam kalangan rakyat Kelantan telah bermula sejak tahun 1920-an dengan tertubuhnya Kelab Putera. Kelab ini dilihat lebih radikal berbanding kelab-kelab lain yang wujud sebelumnya kerana secara tersirat penubuhannya adalah bagi mendapatkan kebebasan daripada penjajah. Penubuhannya pada tahun 1929 dimainkan oleh Saad Shukri bersama Abdul Kadir Adabi dan Haji Osman bin Sulong, dua orang intelektual Melayu di Kelantan pada waktu itu. Saad Shukri yang dilahirkan pada 25 Februari 1905 di Kampung Masjid, Kota Bharu merupakan antara tokoh yang memainkan peranan memberikan asas bagi membangunkan sebuah negara merdeka melalui penulisannya. Melalui usahanya itu beliau berusaha memupuk dan menyuburkan semangat masyarakat Kelantan ke arah memperjuangkan kebangkitan bangsa dan kedaulatan bahasa Melayu. ${ }^{1}$

Kelab Putera dikatakan pernah menghantar memorandum kepada penasihat British menegaskan bahawa orang Melayu Kelantan tidak rela, walaupun seinci buminya dimiliki oleh orang asing, terutamanya dalam kawasan bandar seperti Kota Bharu, Pasir Mas, Pasir Puteh dan Bachok. Kelab ini juga berjaya menerbitkan Majalah Putera dengan penerbitan pertamanya pada 1 October 1929. ${ }^{2}$ Pemimpin Kelab Putera juga turut mendesak pemerintah Inggeris agar tidak mendiskriminasi masyarakat Melayu dalam bidang pelajaran dan menyatakan keazamannya agar sebuah sekolah Inggeris ditubuhkan di Kelantan. ${ }^{3}$ Usaha ini membawa kepada penubuhan Ismail English School Kota Bharu (sekarang dikenali sebagai Maktab Sultan Ismail) pada tahun 1936 yang merupakan sekolah Inggeris yang pertama di Kelantan. Namun begitu, Kelab Putera tidak dapat bertahan lama apabila pemerintah Inggeris yang menganggap kegiatan kelab ini merbahaya kepada pemerintahnya lalu mengaitkan kelab ini dengan Parti Komunis Indonesia. ${ }^{4}$ Teraju utama kelab ini adalah Saad Shukri dan setiausahanya iaitu Safiah bt Yusuf telah ditahan dan majalah Putera turut diharamkan. Penahanan ini menyebabkan kegiatan Kelab Putera menjadi lumpuh. ${ }^{5}$

Kesedaran berpolitik makin berkembang di Kelantan dengan tertubuhnya Persatuan Melayu Kelantan (PMK) pada 20 April 1939. ${ }^{6}$ Namun begitu, keanggotaan PMK hanya terhad kepada golongan kelas atasan yang mempunyai latar belakang pendidikan Inggeris dan pegawai aristokrat Melayu di negeri Kelantan. ${ }^{7}$ PMK yang bergerak aktif dalam bidang politik dan ini membolehkan kesedaran politik dan semangat kebangsaan turut disebarkan dalam kalangan orang Melayu Kelantan. PMK diketuai oleh Nik Yahya bin Nik Daud, sementara 
setiausahanya ialah Haji Othman bin Tahir dan bendaharinya ialah Ahmad Ismail. Manakala anggota lain terdiri daripada pegawai kerajaan seperti Haji Abdullah bin Mahmud, Nik Hassan bin Haji Wan Ahmad dan Ismail Mahmud. ${ }^{8}$ Walaupun PMK mengambil pendekatan sederhana dalam perjuangannya, namun penubuhannya tidak diluluskan oleh pemerintah British. British bimbang orang Melayu Kelantan akan sedar tentang hak-hak mereka jika mereka berpersatuan dan ini akan menimbulkan masalah kepada pentadbirannya. Matlamat British adalah untuk mengaut keuntungan sebanyak mungkin dari Tanah Melayu dan membiarkan pribuminya terus ketinggalan. ${ }^{9}$

Selain PMK, persatuan lain yang ditubuhkan di Kelantan ketika itu ialah Persekutuan Persetiaan Melayu Kelantan (PPMK). PPMK ditubuhkan pada 31 Ogos 1940 atas usaha gigih Nik Mahmood bin Ab. Majid. ${ }^{10}$ Presiden pertama PPMK adalah Tengku Mahmood bin Sultan Muhammad IV dan Nik Mahmood pula memegang jawatan setiausaha. Anggota-anggota lain terdiri daripada Haji Wan Muhammad bin Haji Wan Ahmad (Dato Bentara Dalam), Dato' Haji Ishak Lotfi, Muhammad Asri bin Haji Muda dan Khaidir Khatib. ${ }^{11}$ Keanggotaan PPMK adalah terdiri daripada golongan berpendidikan Melayu dari bandar Kota Bharu dan bandar-bandar lain di negeri Kelantan. Bilangan anggotanya sehingga Disember 1940 adalah seramai kira-kira 850 orang. ${ }^{12}$ Jika dibuat perbandingan antara PMK dan PPMK, dapat dilihat bahawa PPMK adalah sebuah pertubuhan yang agak kekirian, bahkan ada juga yang berpendapat PPMK cenderung kepada aliran sosialis. ${ }^{13}$ Pemimpin PPMK dengan lantang mengkritik kelalaian pemerintah British dalam memberikan pendidikan kepada penduduk Kelantan. ${ }^{14}$ Pergerakan PPMK adalah lebih berpengaruh berbanding PMK dan kehadirannya lebih diterima oleh masyarakat Melayu Kelantan disebabkan keanggotaannya terbuka kepada semua golongan tidak kira mereka daripada golongan atasan mahupun kelas bawahan. Melalui inisiatif yang diambil oleh PPMK tidak kurang lima ratus buah sekolah Melayu telah berjaya ditubuhkan bagi memberikan pendidikan kepada anak-anak Melayu. ${ }^{15}$

Menjelang kedatangan kegiatan politik ditumpukan kepada Kesatuan Melayu Muda (KMM) dengan cawangannya Kelantan ditubuhkan pada tahun 1940. ${ }^{16}$ Penubuhan KMM cawangan Kelantan ini menandakan bermulanya gerakan berhaluan kiri di Kelantan. Pemimpin KMM di negeri Kelantan kebanyakannya terdiri daripada pemimpin persatuan-persatuan terdahulu seperti Abdul Kadir Adabi, Saad Shukri dan Wan Ibrahim bin Mustafa. Keahlian KMM adalah terbuka kepada semua golongan dan kebanyakan ahlinya adalah daripada golongan bawahan. ${ }^{17}$ Pada bulan Disember 1941, KMM cawangan Kelantan telah 
menerbitkan majalah Matahari untuk menyuarakan pendapat mereka terhadap nasib yang menimpa masyarakat Melayu. Melalui majalah ini, KMM pernah membuat tuduhan bahawa golongan pembesar di Kelantan sebagai alat kepada British. Penerbitan majalah ini telah dihentikan selepas pendudukan Jepun pada tahun $1942 .{ }^{18}$ Sepanjang pemerintahan Jepun, tidak ada kelab yang menjalankan kegiatan sehinggalah Jepun menyerah kalah pada tahun 1945. Parti Kebangsaan Melayu Malaya (PKMM) yang merupakan lanjutan daripada KMM telah ditubuhkan dengan cawangan pertamanya di Pasir Puteh, Kelantan. PKMM telah memainkan peranan meneruskan perjuangan KMM yang memperjuangkan kemerdekaan Tanah Melayu. ${ }^{19}$

Sebaik-baik sahaja Perang Dunia Kedua tamat dan British kembali semula, seluruh Tanah Melayu telah diletakkan di bawah pengawasan British Military Administration (BMA). BMA merupakan pentadbiran bercorak tentera oleh British sebelum Malayan Union diperkenalkan. BMA diketuai oleh Ketua Pegawai Hal Ehwal Awam, iaitu Sir Ralph Hone. Tujuan BMA adalah untuk melaksanakan pentadbiran peralihan sebelum sebuah pentadbiran awam diperkenalkan. Kejayaan BMA yang terpenting ialah menghapuskan ancaman Parti Komunis Malaya (PKM) di bawah tentera Bintang Tiga yang memerintah selama 14 hari di Tanah Melayu. BMA juga berjaya mengawal dan menghentikan pergaduhan kaum, mewujudkan keamanan dan menegakkan undang-undang. Kesan pemerintahan BMA adalah kejayaannya mengamankan Tanah Melayu dan membolehkan British perkenalkan Malayan Union. ${ }^{20}$

Selepas pendudukan Jepun, persatuan seperti PMK dan PMKK kembali aktif. Beberapa buah badan yang berbentuk politik juga turut ditubuhkan, termasuklah Persetiaan Melayu, Gabungan Persekutuan Pemuda Melayu Kelantan yang merupakan sebuah persekutuan yang menggabungkan Suara Muda, Persekutuan Pemuda Melayu, Pertubuhan Remaja Pemimpin dan Pemuda Asuhan Bekerjasama. ${ }^{21}$ Persekutuan Pemuda Melayu ditubuhkan oleh golongan pemuda lulusan Ismail English School. Pertubuhan Remaja Pemimpin (PERUPA) pula didirikan oleh golongan lulusan Sekolah Melayu Majlis, manakala Pemuda Asuhan Bekerjasama diasaskan oleh golongan lulusan Sekolah Arab Majlis. Pertubuhan-pertubuhan ini berbentuk politik dan memperjuangkan cita-cita politik untuk masyarakat Melayu Kelantan. ${ }^{22}$ PPMK pula disusun semula dengan mereka yang berpendidikan Timur Tengah membarisi barisan kepimpinannya yang utama. Mereka terdiri daripada Haji Muhammad bin Ahmad sebagai presiden dan setiausaha pula dipegang oleh Ishak Lotfi Omar. ${ }^{23}$ Pada masa ini PPMK semakin aktif melibatkan diri dalam politik. Tokoh-tokoh lain di dalam PPMK 
termasuklah Haji Mohd Daud Salleh, Ahmad Busu, Cikgu Daud Abdul Jalil dan Ustaz Wan Sulaiman Ibrahim. ${ }^{24}$

Melalui peranan yang dimainkan oleh akhbar dan persatuan Melayu di Kelantan pada waktu tersebut dalam usaha menyeru orang Melayu bersatu menentang pelaksanaan Malayan Union telah berjaya dilakukan dengan berkesan. Rakyat Kelantan disedarkan bahawa pelaksanaan Malayan Uniom merupakan suatu pendekatan penjajah untuk menghapuskan hak bangsa Melayu. ${ }^{25}$ Pada 5 Februari 1946, Nik Ahmad Kamil bagi pihak kakitangan kerajaan Kelantan telah menghantar satu telegram bantahan terhadap MU kepada kerajaan British di London. ${ }^{26}$

Ketika Malayan Union diperkenalkan kepada orang Melayu, partiparti politik muncul dengan banyaknya dengan tujuan menentang gagasan ini secara berorganisasi. Di setiap negeri lahir pertubuhan politik seperti SEBERKAS di Kedah, Kesatuan Melayu Johor dan Lembaga Melayu Johor di Johor dan PPMK di Kelantan. Bersama-sama dengan beberapa parti politik yang bersifat kebangsaan seperti PKMM, orang Melayu bersatu dan mengadakan perarakan menentang Malayan Union dikebanyakan kota-kota besar seperti di Johor Bahru, Alor Setar dan Kota Bharu. ${ }^{27}$ Di Kota Bharu, demonstrasi dan perarakan rakyat menentang Malayan Union disertai lebih kurang 20,000 orang yang berhimpun di Padang Bank (kini Padang Merdeka) dan berarak menuju ke tempat penginapan residen British untuk membacakan protes. Surat protes itu telah dibacakan oleh Haji Abu Bakar al-Ahmadi. Seterusnya perarakan bergerak menuju Istana Seri Cemerlang, tempat bersemayam DYMM Sultan Ibrahim ibni Almarhum Sultan Muhammad IV. Di sini surat bantahan telah dibacakan oleh Mohd. Asri Haji Muda. ${ }^{28}$

\section{Penubuhan UMNO Kelantan}

Selepas Jepun menyerah kalah pada 15 Ogos 1945, kerajaan British telah menghantar tenteranya untuk menguasai semula Semenanjung Tanah Melayu, dan serentak dengan itu perubahan radikal cuba dilakukan ke atas pemerintahan Negeri-negeri Melayu. Melalui tipu helah, raja-raja Melayu telah dipengaruhi supaya menandatangani perjanjian dengan wakil kerajaan British, Harold MacMicheal bagi menyerahkan kuasa pemerintahan dan kedaulatan kepada kerajaan British. Apabila cara pemerintahan baru di Semenanjung Tanah Melayu diumumkan di Parlimen British pada 10 Oktober 1945, orang Melayu dari Perlis hingga Singapura, melalui persatuan masing-masing, berkumpul dan bersuara membantah penubuhan Malayan Union. 
Perhimpunan besar-besaran yang pertama telah diadakan di Kelab Sultan Sulaiman, Kuala Lumpur pada 1 hingga 4 Mac 1946. ${ }^{29}$ Perhimpunan yang diadakan di Kelab Sultan Sulaiman ini turut dihadiri oleh PPMK dan PMK. PPMK diwakili oleh Haji Fadlullah Suhaimi, Mohamad bin Busu dan Haji Lofti Omar, manakala PMK diwakili oleh Nik Ahmad Kamil bin Nik Mahmud, Haji Ahmad Mahir Ismail dan Ismail Ibrahim. ${ }^{30}$ Pada waktu tersebut telah timbul kesedaran dalam kalangan orang Melayu bahawa perjuangan mereka tidak akan berjaya jika dilakukan secara bersendirian dan berpuak-puak, tetapi sebaliknya memerlukan perpaduan dan pengembelengan tenaga yang kukuh. Perhimpunan ini telah berjaya menghasilkan satu resolusi bagi membentuk sebuah organisasi pusat yang diberi nama United Malays National Organization (UMNO). ${ }^{31}$

Kongres Kebangsaan Melayu kali ketiga yang diadakan di Johor Bahru pada 11 Mei 1946 telah membawa kepada penubuhan UMNO secara rasmi. PMK yang menyertai perhimpunan tersebut dengan rasminya menjadi gabungan UMNO dan serentak dengan itu PMK pun dibubarkan. Pembubaran PMK dan penggabungannya ke dalam UMNO telah menjadikannya cabang UMNO di negeri Kelantan. PPMK dengan dibantu oleh PMK, PERUPA dan Pemuda Asohan bekerjasama telah menjadi tuan rumah kepada persidangan UMNO yang diadakan di Kota Bharu pada 9 hingga 13 Mei 1947. Persidangan ini telah dirasmikan oleh DYMM Sultan Ibrahim, sultan yang memerintah negeri Kelantan pada ketika itu. ${ }^{32}$

Ketika ditubuhkan UMNO Kelantan dipimpin oleh Tengku Ahmad bin Tengku Abdul Ghafar, seorang pegawai kerajaan daripada golongan bangsawan, manakala Haji Mahmud Muhayidin bin Tengku Abdul Kamaruddin telah dilantik menjadi Pegawai Perhubungan UMNO. Beliau memegang jawatan itu dari tahun 1951 hingga 1952. Selain beliau, pemimpin berkaliber yang turut memimpin UMNO Kelantan pada waktu itu adalah Nik Ahmad Kamil, Kamaruddin bin Haji Idris, Ismail Mahmud dan Ismail Ibrahim. Nik Ahmad Kamil merupakan anak sulung kepada bekas Menteri Besar Kelantan, Datuk Nik Mahmud bin Nik Ismail. Beliau dilahirkan pada tahun 1909 dan merupakan orang Melayu Kelantan pertama dihantar belajar ke luar negara. Beliau belajar di University of Bristol mengambil bidang undang-undang. Nik Ahmad Kamil adalah seorang dihormati kerana kebijaksanaannya. Ketika Harold Mac Michael melawat Sultan Kelantan pada tahun 1946 untuk mendapatkan persetujuan MU, baginda mengakui bahawa Nik Ahmad Kamil adalah seorang yang bijak, berpendidikan tinggi serta seorang yang berfikiran progresif. ${ }^{33}$ 
Kehadiran pemimpin berkaliber seperti Nik Ahmad Kamil membolehkan UMNO Kelantan terus melangkah ke hadapan dalam perjuangannya. Pengaruh UMNO terus berkembang ke seluruh daerah di negeri Kelantan dengan penubuhan cawangan sehingga keahliannya meningkat kepada 2,345 orang pada tahun 1949. ${ }^{34}$ Peningkatan jumlah ahli ini telah membawa kepada penukaran UMNO bahagian Kelantan kepada UMNO negeri Kelantan pada tahun 1950. Apabila UMNO bahagian Kelantan dinaiktarafkan sebagai UMNO negeri membolehkan UMNO cawangan pula dinaik taraf sebagai UMNO bahagian. UMNO bahagian yang ditubuhkan pada tahun 1950, termasuklah UMNO Bahagian Kota Bharu, Tumpat, Pasir Mas, Pasir Puteh, Bachok dan Ulu Kelantan, manakala UMNO Bahagian Machang ditubuhkan pada tahun 1952. Walau bagaimanapun, hanya tiga buah bahagian UMNO sahaja yang aktif, iaitu UMNO Bahagian Tumpat, Pasir Mas dan Pasir Puteh, sedangkan UMNO bahagian-bahagian lain, bilangan ahlinya agak terhad dan tidak aktif. ${ }^{35}$

Pada tahun 1951, UMNO telah dilanda krisis kepimpinan yang rumit berikutan perletakan jawatan Dato' Onn bin Jaafar sebagai Presiden UMNO. Dato' Onn bertindak demikian kerana tidak puas hati dengan UMNO yang tidak mahu membuka pintu keahliannya kepada kaum-kaum lain. Pada pendapat beliau Tanah Melayu tidak akan diberikan kemerdekaan oleh British jika diperjuangkan oleh sebuah parti yang mewakili satu kaum sahaja. ${ }^{36}$ Usul Dato' Onn ini ditolak oleh ahli-ahli UMNO kerana merasa tersinggung dengan cadangan yang boleh mencairkan pengaruh orang Melayu dalam UMNO. ${ }^{37}$

Krisis kepimpinan ini turut dirasa oleh UMNO Kelantan dan keadaan ini telah membantutkan perkembangannya di negeri tersebut. Ini disebabkan pemimpin UMNO Kelantan ketika itu seperti Nik Ahmad Kamil bertindak meninggalkan UMNO untuk menyertai parti pimpinan Dato' Onn. UMNO Kelantan terus berada dalam suasana membeku diri dan memerhati keadaan yang berlaku dalam UMNO pusat, supaya tindakannya selari atau tidak bercanggah dengan UMNO. Keadaan ini berlarutan hinggalah UMNO Kelantan berjaya dipulihkan menjelang tahun 1954 dengan lawatan Syed Jaafar Albar ke negeri tersebut bagi mengadakan majlis penerangan di Tumpat, Kota Bharu, Pasir Puteh dan Bachok. Lawatan ini telah mendapat sambutan menggalakkan daripada masyarakat setempat dan memberi nafas baru kepada UMNO Kelantan. ${ }^{38}$

Pada tahun 1954 juga, Pergerakan Pemuda UMNO telah ditubuhkan secara rasmi di Kota Bharu, Pasir Mas dan Pasir Puteh. UMNO terus giat mencari ahli dan berjaya mengumpulkan ahli yang kebanyakannya terdiri pegawai kerajaan dan juga dalam kalangan bangsawan. Hanya sebahagian kecil sahaja mereka yang menyertai 
UMNO daripada orang awam kerana ketika itu kesedaran orang ramai terhadap politik masih belum begitu meluas. ${ }^{39}$

\section{Perkembangan UMNO ke Pasir Mas}

UMNO bahagian Pasir Mas ditubuhkan oleh Y.M Tengku Ahmad Tengku Abd Ghaffar yang merupakan Ketua Jajahan Pasir Mas dengan dibantu Dato Hashim, Penolong Ketua Jajahan Pasir Mas. Penubuhannya telahpun berlaku secara tidak rasmi pada tahun 1950 oleh beberapa orang yang terlibat dalam penentangan terhadap MU. Idea penubuhan UMNO Bahagian Pasir Mas ini bermula di sebuah rumah membasuh kain di tebing Sungai Lemal. Pada awal penubuhannya, keahlian UMNO Bahagian Pasir Mas hanyalah seramai 14 orang dan mereka kesemunya merupakan penduduk di sekitar bandar Pasir Mas. Tengku Ahmad telah dilantik sebagai Ketua UMNO Bahagian Pasir Mas, manakala Dato Hashim sebagai timbalannya. Anggota-anggota lain terdiri daripada Encik Daud Salleh, seorang kerani di Pejabat Tanah Pasir Mas yang dilantik sebagai setiausaha; Encik Yaacob Awang, seorang peniaga dilantik sebagai bendahari, manakala Ahli Jawatan Kuasa (AJK) pula terdiri daripada Encik Abdullah bin Ibrahim dari Pengkalan Pasir; Encik Omar bin Ali dari Kampung Dangar; Encik Nik Yusof bin Nik Nordin dari Lemal dan Encik Ismail bin Ibrahim dari Bandar Pasir Mas. Pada masa tersebut terdapat hanya empat cawangan UMNO di Pasir Mas dan keahliannya terus berkembang dengan kemasukan ahli-ahli dari kampung-kampung berdekatan. ${ }^{40}$

Keinginan untuk menubuhkan UMNO di Pasir Mas sebenarnya timbul selepas penubuhan UMNO pada tahun 1946 lagi. Perkara ini berlaku kerana beberapa orang penduduk Pasir Mas telah turut sama menyertai perhimpunan di Padang Merdeka membantah MU yang turut dihadiri seramai 10,000 hingga 15,000 orang rakyat Kelantan. Namun begitu. keinginan itu terkubur begitu sahaja kerana tiada pemimpin yang betul-betul bersedia memimpinnya sehinggalah kehadiran Tengku Ahmad yang menjadi pemimpin kepada usaha tersebut. ${ }^{41}$

Pada peringkat awal penubuhannya, UMNO Bahagian Pasir Mas tidaklah aktif, cuma wujud sekadar pada nama sahaja. Keadaan ini berlaku kerana ketiadaan pemimpin yang berkebolehan dalam kalangan bukan pegawai kerajaan. Perkara ini adalah kerana pihak British telah mengeluarkan arahan melarang penglibatan pegawai-pegawainya dalam politik. Keadaan ini berlarutan sehingga tahun 1954. Namun demikian, menjelang akhir tahun 1954 banyak cawangan UMNO yang tidak aktif ini telah berjaya dipulihkan, termasuklah UMNO Pasir Mas. ${ }^{42}$ Pada tahun 1955, UMNO Pasir Mas masih belum dirasmikan lagi dan hanya menjadi bilik gerakan pilihan raya berikutan arahan UMNO 
Pusat sempena pilihan raya pertama pada tahun 1955. Pada waktu ini UMNO Pasir Mas telah dicantumkan dengan UMNO Tanah Merah kerana kawasan Tanah Merah diletakkan di bawah Parlimen Pasir Mas. ${ }^{43}$

Kegiatan pemuda UMNO di Kelantan pada tahun 1950-an banyak berpusat di Pasir Mas dan keadaan inilah yang mendorong penubuhan UMNO Bahagian Pasir Mas secara rasmi pada Jun 1956 bertempat di Kelab Pasir Mas oleh Encik Sardon Haji Zubir, Ketua Pemuda UMNO Pusat pada masa tersebut. ${ }^{44}$ Keanggotaan pertama UMNO Pasir Mas secara rasmi terdiri dalam kalangan guru dan aktivitinya pada peringkat awal banyak dikendalikan oleh golongan pemuda. Namun begitu, selepas penubuhannya secara rasmi, UMNO Bahagian Pasir Mas telah menjalankan kegiatannya di bawah UMNO negeri kerana UMNO Pasir Mas tidak mempunyai pemimpin. Perkara ini berlaku kerana pemimpin-pemimpin dalam kalangan guru bertindak keluar UMNO secara beramai-ramai berikutan rasa tidak puas hati terhadap isu bahasa Melayu yang diperjuangkan secara sambil lewa oleh parti tersebut. ${ }^{45}$

UMNO Pasir Mas juga dilanda krisis apabila pemimpinnya bertindak keluar parti. Laporan akhbar Mingguan Pedoman menyatakan bahawa UMNO bahagian Pasir Mas berhadapan dengan krisis yang paling hebat kerana berlakunya pertelingkahan antara beberapa orang ahli jawatankuasa bahagian itu dengan pengerusinya, Yang Berhormat Encik Yaacob Awang. Akibatnya krisis yang berlaku beberapa Ahli Jawatankuasa bahagian itu meletak jawatan masing-masing dan kemudian menyertai PAS. ${ }^{46}$

\section{Penubuhan Parti Islam SeMalaya (PAS) Kelantan}

Pemikiran tentang Islam dan nasionalisme dalam konteks perjuangan kemerdekaan hanya dapat dilihat secara tersusun selepas Perang Dunia Kedua. PAS muncul hasil pengaruh beberapa gerakan Islam yang lebih awal seperti Ikhwanul Muslimun di Mesir, Masyumi di Indonesia dan Jamaat Islami di Pakistan. Pengaruh ini tersebar ke Tanah Melayu melalui peranan yang dimainkan oleh mereka yang pernah melanjutkan pelajaran di Mesir, Makkah, India dan Indonesia. Golongan berpendidikan agama yang mewakiki kelompok ulama menyedari bahawa umat Islam memerlukan sebuah pertubuhan atau badan yang boleh mewakili mereka dalam semua aspek kehidupan, terutamanya dalam keadaan Tanah Melayu sedang dijajah oleh British ketika itu. Kesedaran ini kemudiannya membawa kepada penubuhan Majlis Tertinggi Agama Malaya (MATA) pada 1947, diikuti oleh Hizbul Muslimin (HAMIM) pada $1948 .^{47}$ 
HAMIM merupakan pertubuhan politik Islam yang pertama di Tanah Melayu. Penubuhannya adalah hasil kongres rakyat yang terbesar yang diadakan di Gunung Semanggol atas inisiatif Ustaz Abu Bakar al-Baqir, iaitu seorang ulama yang terkenal dengan sokongan Dr. Burhanuddin Al Helmy. HAMIM berjaya mengadakan penerangan di seluruh negara bermula dari Kampung Dong, Raub Pahang, Kuala Terengganu, Kuala Berang, Dungun, Besut dan seterusnya ke Kelantan. Penerangan juga turut meliputi kawasan utara seperti di negeri Kedah, Perlis, dan Pulau Pinang. ${ }^{48}$ Gerakan politik Islam ini bagaimanapun tidak dapat bertahan lama berikutan penguatkuasaan Ordinan Darurat pada bulan Jun 1948 di seluruh Tanah Melayu. Pengisytiharan Darurat ini menyebabkan seluruh parti politik yang tidak bekerjasama dengan pemerintah British, termasuklah HAMIM diharamkan. Pembentukan HAMIM ini merupakan asas dalam sejarah pembentukan PAS. ${ }^{49}$

Sejarah perkembangan awal yang membawa kepada penubuhan PAS oleh Haji Ahmad Fuad Hassan mempunyai kaitan dan pertalian dengan UMNO. Keadaan ini dapat dilihat dalam pentadbiran UMNO itu sendiri yang telah mewujudkan satu badan ulama yang menguruskan hal ehwal keagamaan yang ketuai oleh Haji Ahmad Fuad Hassan. Badan ulama turut mengambil bahagian dalam Kongres Islam yang telah diadakan di Gunung Semanggol. ${ }^{50}$ Sebahagian besar ahlinya merasakan bahawa terdapat kekosongan dalam bidang dan ruang gerakan politik jika Islam tidak disertakan bersama. Dalam tulisannya, "Ulamak Malaya Belum Bersatu dan Belum Punya Persatuan”, Haji Ahmad Fuad menyifatkan kedudukan ulama ketika itu umpama sampah yang tidak dihargai kerana tiada kekuatan. Golongan ulama juga telah jemu dengan sikap UMNO yang mengabaikan isu Natrah, penganjuran judi Loteri Kebajikan Masyarakat, menganjurkan fun fair dan lain-lain yang tidak memperlihatkan komitmen serius parti tersebut kepada perjuangan menegakkan Islam. Dalam satu persidangan ulama yang dipimpin oleh Sheikh Abdullah Fahim, Mufti Pulau Pinang di Seberang Perai pada 1951, fatwa dikeluarkan yang mengharamkan judi Loteri Kebajikan Masyarakat anjuran UMNO yang diwujudkan pada tahun 1951. ${ }^{51}$ Akhbar Utusan Melayu pada 19 Ogos 1951 turut menerbitkan fatwa yang mengharamkan loteri ini. Berikutan fatwa yang dikeluarkan, Setiausaha Loteri Kebajikkan UMNO telah menghantar surat kepada bendahari UMNO Malaya, iaitu Tuan Shaikh Ahmad Bin Mohd Hashim. Walaupun fatwa tentangnya telah dikeluarkan pada tahun 1951, namun pada tahun 1953 loteri tetap dijadikan sumber ekonomi UMNO. ${ }^{52}$

Pada 23 Ogos 1951 dalam persidangan ulama di Kuala Lumpur, mereka yang mendukung perjuangan ulama ini bersetuju menubuhkan sebuah persatuan yang dinamakan Persatuan Ulama Se-Malaya. Haji 
Ahmad Fuad Hassan telah dilantik menjadi Yang Dipertua, walaupun pada masa itu beliau masih menjadi ahli jawatankuasa UMNO. ${ }^{53} \mathrm{Nama}$ persatuan ini kemudiannya diubah menjadi Persatuan Islam Se-Malaya (PAS) pada 24 November 1951 dalam satu lagi persidangan ulama Malaya yang diadakan di Bagan Tuan Kecil (Butterworth), Seberang Prai. Sejak itu PAS berkembang menjadi sebuah pertubuhan politikdakwah yang penting di negara ini yang turut memperjuangkan kemerdekaan Tanah Melayu. ${ }^{54}$ PAS dikatakan mewarisi tiga ideologi politik, iaitu ideologi kebangsaan dari UMNO, modenisasi Islam yang dibawa HAMIM dan perjuangan badan-badan anti UMNO sekitar tahun 1950-an. ${ }^{55}$ Berteraskan perjuangan Islam, PAS berjaya menarik sokongan golongan yang cintakan Islam seperti para ulama, ustaz dan pelbagai lapisan masyarakat yang lain yang menolak UMNO. ${ }^{56}$

Penerimaan dan perkembangan PAS di Kelantan berjalan lancar kerana ramai bekas ahli dan pemimpin PPMK menyertai PAS. Mereka termasuklah Haji Ishak Lotfi yang memegang jawatan sebagai Ketua Jabatan Agama di Majlis Agama Islam Kelantan, Haji Mohd Daud bin Salleh, bekas pegawai kerajaan, Tengku Ibrahim Tengku Bakti serta beberapa yang lain, termasuklah Abdul Rahman Sulong yang merupakan ahli PAS yang pertama di Kelantan. ${ }^{57}$

Perkembangan pesat PAS di Kelantan adalah disebabkan arus perjuangan Islam yang telah lama bertapak dalam kalangan tokoh tempatan, khususnya di sekitar Kota Bharu. Pengaruh perjuangan Islam tersebut telah dibawa oleh beberapa pemimpin Masyumi Indonesia yang datang menetap dan melawat Kelantan. Antara mereka yang dimaksudkan ialah Tamee @ Bustamin bin Ismail yang telah datang menetap di Kelantan sejak 1932. Beliau telah bersahabat baik dengan Haji Mohd Daud bin Salleh yang merupakan penulis petisyen bertauliah di Kota Bharu. Berita tentang penubuhan PAS pada 1951 telah sampai ke pengetahuan Bustamin dan Mohd Daud melalui Khaidir bin Khatib yang mengajar agama di Ma'ahad Ehya al-Syariff. Menurut Amaludin Darus, pada masa itu Mohd Asri yang aktif dalam Angkatan Pemuda Insaf (API) telah berpindah ke Perak untuk mengelakkan diri daripada diburu oleh pihak berkuasa British. Beliau kemudian berkahwin dengan Sakinah anak kepada Shaykh Joned Tola yang berasal dari Sumatera. ${ }^{58}$ Mohd Asri pernah mengajar di Ma'ahad Ehya al-Syariff dan di sinilah beliau terpengaruh dengan perjuangan Islam dan kemudian bekerja sebagai pegawai tadbir di Pejabat PAS di Kepala Batas, Seberang Prai selepas penubuhan PAS. ${ }^{59}$

Mohd Asri kemudiannya dilantik sebagai Pesuruhjaya PAS bagi negeri Kelantan dan Terengganu. Mohd. Asri merupakan adik ipar kepada Haji Mohd Daud. Melalui sokongan moral dan kewangan 
yang diberikan oleh Mohd Daud dan Bustamin serta beberapa rakan lain beliau giat berceramah memperkenalkan PAS di sekitar Kota Bharu sehingga berjaya menubuhkan cawangan PAS pertama di Kota Bharu dalam tahun 1952. PAS Kelantan terus berkembang dan berjaya menubuhkan cawangannya di Pasir Mas pada tahun 1953, Tanah Merah pada tahun 1955, Bachok pada tahun 1956, Kuala Krai pada tahun 1958 dan Tumpat pada tahun 1959. ${ }^{60}$ Berpaksikan sebuah parti yang membawa ideologi Islam, PAS berjaya menarik minat para ulama, guru agama serta para petani yang berpegang kuat kepada ajaran Islam. Tambahan pula Kelantan memang terkenal sebagai pusat pengajian Islam sejak sebelum Perang Dunia Kedua lagi dan ini membolehkan parti tersebut mendapat tempat di hati penduduk negeri itu. ${ }^{61}$

\section{Perkembangan PAS ke Pasir Mas}

PAS Pasir Mas yang ditubuhkan pada 23 Julai 1953 merupakan cawangan pertama parti tersebut di Kelantan dan juga di Pantai Timur Semenanjung Tanah Melayu. Penubuhannya adalah atas usaha Amaluddin Darus, seorang anggota bomba yang tertarik dengan penubuhan PAS sejak dari awal penubuhannya. ${ }^{62}$ Beliau seterusnya cuba mencari kawan-kawan yang sealiran dan apabila dipindah untuk berkhidmat di Pasir Mas, beliau berkenalan dengan Ahmad Yatim dan Mohamad Noor Senik yang kemudiannya menjadi tokoh yang turut bergiat menubuhkan PAS di Pasir Mas. ${ }^{63}$

Penduduk Pasir Mas yang terawal menjadi ahli PAS, termasuklah Muhammad Syarif dari Kampung Tal Tujuh, Yusuf Muhammad yang merupakan tukang gambar, Abdul Rahman yang bekerja sebagai tukang jam, Muhammad Nur Hj Senik dan Che Ali yang memiliki kedai emas. ${ }^{64}$ Keahlian PAS terus meningkat sehinggalah menjadi seramai enam puluh orang, termasuklah Omar Yusuf, iaitu seorang saudagar getah di Pasir Mas. Omar Yusuf seterusnya dilantik menjadi ketua cawangan Pasir Mas setelah Amaluddin Darus menolak jawatan tersebut dan beliau hanya bersedia menjadi sebagai setiausaha cawangan. Amaluddin Darus menolak jawatan ketua kerana mahu menumpukan perhatian kepada kerja-kerja kepartian. ${ }^{65}$ Amaluddin Darus bersama-sama Ahmad bin Yatim dan Mohd Noor bin Senik terus menyebarkan PAS ke seluruh negeri Kelantan, khususnya di Pasir Mas dengan pelbagai cara, antaranya ialah dengan berbual-bual di rumah dan di kedai kopi. Kesempatan berbual di kedai kopi dimanfaatkan dengan memperkenalkan dasar perjuangan PAS. ${ }^{66}$

PAS cawangan Pasir Mas terus berkembang dan menjadi antara kubu terpenting PAS di Tanah Melayu amnya dan di Kelantan 
khususnya. Malahan cadangan pemimpinnya Amaluddin Darus dalam menentukan pendirian PAS untuk menyokong National Convention berbanding National Conference telah diterima oleh pemimpin tertinggi parti tersebut. Pada ketika itu, PAS telah dijemput untuk menghadiri kedua-dua persidangan yang dianggap penting. Persidangan yang dikenali sebagai National Conference adalah atas anjuran Datuk Onn Jaafar bersama tujuh orang Menteri Besar, manakala National Convention ditaja oleh Tuanku Abdul Rahman Putra al-Haj (UMNOMCA). ${ }^{67}$

Tujuan National Conference dan National Convention ialah untuk menyelaraskan usaha bagi mencapai kemerdekaan Tanah Melayu dan mencari satu formula dalam menyelesaikan beberapa perkara berbangkit seperti status kerakyatan, hak untuk mengundi dan sebagainya. Berikutan itu, satu Mesyuarat Agung Khas PAS telah diadakan di Tanah Liat, Bukit Mertajam pada 23 September 1953 bagi menentukan pendirian PAS dalam menghadapi kehendak Ahli Jawatankuasa Agung pada masa itu yang berbeza-beza pandangan. Terdapat dalam kalangan mereka menyokong National Convention dan ada yang menyokong National Conference. Ini termasuklah pandangan Haji Ahmad Fuad sendiri yang mencadangkan supaya PAS menyertai National Conference manakala Mohd. Asri pula mencadangkan supaya PAS menyertai National Convention tajaan UMNO. ${ }^{68}$

Saranan Amaluddin Darus telah diterima oleh pimpinan PAS apabila parti tersebut mengambil sikap menyokong National Convention, tetapi tidak terikat kepadanya sekiranya langkah-langkah yang diambil oleh National Convention merugikan bangsa Melayu dan umat Islam. PAS dengan itu telah menolak gagasan yang ditaja oleh Dato' Onn kerana mengiktiraf kerakyatan dan persamaan hak bagi seluruh kaum yang ada di negara ini pada waktu itu. Dengan itu, PAS memilih untuk menghadiri dan menyatakan pendapat di dalam persidangan National Convention yang dianjurkan oleh UMNO. Salah seorang daripada tiga wakil PAS yang dipilih menyertai National Convention adalah Mohd. Asri. ${ }^{69}$

PAS Pasir Mas terus berkembang dan menjelang pilihan raya 1955, keahliannya meningkat menjadi kira-kira 600 orang berbanding hanya 40 orang di Bachok dan 100 orang di Pasir Puteh. ${ }^{70}$ Kegiatan PAS di Pasir Mas terus diperhebatkan dengan mengadakan ceramah dan rapat umum, selain kempen dari rumah ke rumah bagi memperkenalkan PAS kepada penduduk Pasir Mas. Selain itu, turut diadakan juga kursus politik bagi memperkenalkan ideologi dan perjuangan PAS kepada pendukungnya. Kursus ini diadakan disebuah sekolah agama di Kubang Bemban dan program ini diadakan setiap minggu. ${ }^{71}$ 
Masalah yang membelenggui PAS dalam usaha menambah keahliannya adalah masalah kewangan yang terhad. Wang hasil yuran keahlian tidak mencukupi untuk membiayai aktiviti parti, dan malahan pemimpin PAS terpaksa mengeluarkan perbelanjaan sendiri untuk menjayakan kegiatan PAS. Kutipan derma juga telah dilakukan untuk menambah pendapatan bagi menggerakkan aktiviti parti. Masalah kewangan ini tidak hanya dialami PAS Pasir Mas, dan malahan cawangan-cawangan lain seperti Machang dan Kota Bharu. Menurut Penyata Tahunan PAS cawangan Kota Bharu, sehingga tahun 1956 cawangan tersebut menanggung hutang berjumlah RM1634, iaitu suatu jumlah yang tinggi nilainya pada waktu itu. ${ }^{72}$

Keaktifan PAS menambahkan keahliannya terus berjalan lancar, walaupun dibelenggui masalah kewangan. Ini dibuktikan apabila PAS menunjukkan kejayaan dan kemampuannya berdiri sebagai sebuah parti dengan turut mengambil bahagian dalam Pilihan Raya 1955. Penyertaan PAS dalam Pilihan Raya 1955 lebih merupakan latihan semata-mata untuk memperkenalkan PAS kepada rakyat secara terbuka kerana PAS pada waktu itu baru berusia tiga tahun. Penyertaan PAS dalam pilihan raya tersebut tidak mengharapkan kemenangan, tetapi lebih kepada mengharapkan sedikit sinar di Pasir Mas berdasarkan bilangan keahliannya yang tertinggi berbanding cawangan-cawangan lain di negeri Kelantan. Walaupun tewas dalam pilihan raya tersebut, tetapi calon PAS di Pasir Mas merupakan satu-satunya calon parti tersebut di Kelantan yang tidak hilang wang pertaruhan. Penyertaan dalam pilihan raya tersebut telah meningkatkan penerimaan dan sambutan masyarakat terhadap PAS yang menjadi semakin meluas. Gerakan kepartian semasa pilihan raya itu telah memberikan PAS peluang dan kesempatan untuk menyebarkan dasar serta tujuan perjuangannya kepada masyarakat Pasir Mas. ${ }^{73}$

Pengalaman menyertai pilihan raya 1955 membuatkan PAS menyusun jentera partinya dengan lebih intensif dengan memperhebatkan usaha-usaha penerangan oleh barisan kepimpinan di setiap cawangan dengan dibantu oleh Pegawai Perhubungan PAS Kelantan. ${ }^{74}$ Kejayaan usaha tersebut dibuktikan apabila PAS cawangan Pasir Mas berjaya menubuhkan cawangannya yang ke-100 dalam satu perjumpaan yang dihadiri oleh seramai 500 orang pada bulan Februari 1959. ${ }^{75}$ Keadaan ini membuktikan perkembangan PAS yang pesat di Kelantan, khususnya di Pasir Mas. Pada tahun 1959, PAS telah memperoleh satu kejayaan besar yang tidak diduga oleh sesetengah pemimpinnya sendiri apabila berjaya memerintah negeri Kelantan. Kejayaan yang dicapai ini menjadi lebih bermakna apabila PAS berjaya mencapai kemenangan besar di Pasir Mas. ${ }^{76}$ 


\section{Persaingan UMNO dan PAS dalam Pilihan Raya 1955}

Pilihan raya pertama di Kelantan diadakan pada tahun 1955 dengan Pilihan Raya Parlimen pada bulan Julai, diikuti Pilihan Raya Dewan Undangan Negeri (DUN) pada bulan September tahun yang sama. Pilihan raya ini diadakan sebagai langkah awal ke arah kemerdekaan Tanah Melayu. Minat penduduk di Kelantan terhadap pemilihan pemimpin melalui proses undian yang mewakili mereka sebenarnya telah lama wujud. Ini sudah bermula dengan penglibatan mereka dalam memilih imam-imam surau dan masjid masing-masing yang dilakukan melalui pemilihan mereka yang mendapat sokongan ramai. ${ }^{77}$

Dalam Pilihan Raya 1955, UMNO Pasir Mas dilihat tidak mempunyai pesaing yang mencabar kerana penubuhannya lebih awal berbanding PAS. Perbezaan tiga tahun dengan penubuhan PAS membolehkan UMNO terlebih dahulu mengukuhkan kedudukan dalam kalangan rakyat Pasir Mas. Persaingan UMNO mungkin hanya datang dari Parti Negara, namun parti tersebut tidak meletakkan calonnya di Pasir Mas. Pada waktu itu dasar yang diperjuangkan PAS belum meluas penerimaannya dalam kalangan masyarakat kerana masih ramai yang belum menyedari kewujudannya dan tidak mengetahui dasar Islam yang menjadi perjuangannya. UMNO merasakan adalah tidak sukar baginya mendapatkan undi memandangkan semua rakyat tidak kira lapisan memberikan sokongan waktu itu dalam rangka menentang penjajahan. Ini bersesuaian dengan dasar UMNO yang inginkan kemerdekaan dicapai dalam masa yang singkat tanpa melibatkan pertumpahan darah. ${ }^{78}$

Sebagai sebuah parti politik yang jelas bercita-cita menegakkan negara Islam yang mengamalkan Islam secara menyeluruh dalam setiap aspek kehidupan rakyatnya, PAS menggunakan landasan pilihan raya sebagai salah satu cara untuk mencapai cita-cita tersebut. PAS menyertai Pilihan Raya 1955 berdasarkan kaedah fekah yang mengatakan 'Apabila bertemu dua mudharat, maka hendaklah dipilih yang lebih ringan'. ${ }^{79}$ Bagi PAS yang baru sahaja ditubuhkan ketika itu tanpa menyertai pilihan raya, umat Islam akan lebih mudah dikuasai oleh musuhmusuh Islam dan kuncu-kuncunya. Ini dianggap sebagai mudarat yang lebih besar dan berat. Oleh itu, PAS berpendirian bahawa menyertai pilihan raya adalah suatu kewajiban tidak kira sama ada mempunyai peluang untuk menang atau sebaliknya. Walaupun hanya ditubuhkan secara rasmi tidak lama sebelum Pilihan Raya 1955 diadakan, namun PAS Pasir Mas yang diketuai Omar Yusuf berjaya menambahkan keahliannya sebanyak sepuluh kali ganda, iaitu daripada 60 orang semasa penubuhannya kepada 600 orang menjelang pilihan raya. ${ }^{80}$ 
UMNO Pasir Mas meletakkan Tengku Ahmad bin Tengku Ghaffar sebagai calon bagi kerusi Parlimen. Tengku Ahmad merupakan seorang kerabat diraja dan pada waktu itu berumur 47 tahun. Beliau mempunyai pengaruh yang besar ketika itu di Pasir Mas. ${ }^{81}$ PAS pula mempertaruhkan Haji Mokhtar Ahmad yang berumur 45 tahun, iaitu adik kepada Haji Abdullah Tahir Bunut Payong, seorang ulama yang terkenal. ${ }^{82}$ Bagi kerusi DUN, UMNO Pasir Mas telah meletakkan caloncalonnya pada ketiga-tiga kerusi DUN yang dipertandingkan. Mereka terdiri daripada Che Omar Haji Ali (Pasir Mas Utara), Yaacob Awang (Pasir Mas Selatan) dan Che Abdul Rahim Daud (Pasir Mas Tengah). PAS pula hanya meletakkan calon-calonnya di Pasir Mas Utara, iaitu Haji Awang Abdul Samad dan di Pasir Mas Tengah, iaitu Che Abdullah Ahmad. $^{83}$

Keputusan Pilihan Raya Parlimen Kelantan 1955

\begin{tabular}{|c|c|c|c|}
\hline Kawasan pilihan raya & Nama calon & \begin{tabular}{|c|}
$\begin{array}{c}\text { Perolehan } \\
\text { undi }\end{array}$ \\
\end{tabular} & \begin{tabular}{|c|c|} 
Majoriti \\
undi
\end{tabular} \\
\hline $\begin{array}{l}\text { Pasir Mas } \\
\text { Peratusan keluar } \\
\text { mengundi : } \\
84.6 \text { peratus }\end{array}$ & $\begin{array}{l}\text { Tengku Ahmad bin Tengku } \\
\text { Idris (UMNO) } \\
\text { Hj Mokhtar Hj Ahmad (PAS) }\end{array}$ & $\begin{array}{l}20963 \\
7507 \\
\end{array}$ & 13456 \\
\hline $\begin{array}{l}\text { Kelantan Utara } \\
\text { Peratusan keluar } \\
\text { mengundi : } \\
84.8 \text { peratus }\end{array}$ & $\begin{array}{l}\text { Tengku Indera Petra } \\
\text { (UMNO) } \\
\text { Datuk Nik Hussein bin Zainal } \\
\text { (Negara) }\end{array}$ & $\begin{array}{l}28428 \\
6295\end{array}$ & 22133 \\
\hline $\begin{array}{l}\text { Kelantan Tengah } \\
\text { Peratusan keluar } \\
\text { mengundi : } \\
79.3 \text { peratus } \\
\end{array}$ & $\begin{array}{l}\text { Abdul Hamid bin Mahmud } \\
\text { (UMNO) } \\
\text { Tg Anuar Zainal (Negara) } \\
\text { Nik Muhammad bin Dato } \\
\text { Amar (Bebas) } \\
\text { Idris Hj Mohamed (Bebas) }\end{array}$ & $\begin{array}{l}28422 \\
2970 \\
1154 \\
721 \\
\end{array}$ & 25452 \\
\hline $\begin{array}{l}\text { Kelantan Selatan } \\
\text { Peratusan keluar } \\
\text { mengundi : } \\
86.1 \text { peratus } \\
\end{array}$ & $\begin{array}{l}\text { Abdul Khalid bin Awang } \\
\text { (UMNO) } \\
\text { Dato Nik Ahmad Kamil } \\
\text { (Negara) } \\
\text { Hj Mohamed Noor (PAS) } \\
\end{array}$ & $\begin{array}{l}21746 \\
7175 \\
3600 \\
\end{array}$ & 14571 \\
\hline
\end{tabular}

Sumber: Mohd. Zain Salleh, Sejarah UMNO Kelantan, Jawatankuasa Penerangan Perhubungan UMNO Negeri Kelantan, 1985, hlm. 222. 
Keputusan Pilihan raya DUN Pasir Mas 1955

\begin{tabular}{|c|c|c|c|}
\hline Kawasan pilihan raya & Nama calon & $\begin{array}{c}\text { Perolehan } \\
\text { undi }\end{array}$ & $\begin{array}{c}\text { Majoriti } \\
\text { undi }\end{array}$ \\
\hline Pasir Mas Selatan & Yaacob bin Awang(UMNO) & $\begin{array}{c}\text { Menang } \\
\text { tanpa } \\
\text { bertanding }\end{array}$ & \\
\hline $\begin{array}{l}\text { Pasir Mas Utara } \\
\text { Jumlah pengundi } \\
\text { berdaftar: } \\
11975\end{array}$ & $\begin{array}{l}\text { Che Omar Hj Ali (UMNO) } \\
\text { Hj. Awang Abdul Samad } \\
\text { (PAS) }\end{array}$ & $\begin{array}{l}5611 \\
1595\end{array}$ & 4016 \\
\hline $\begin{array}{l}\text { Pasir Mas Tengah } \\
\text { Jumlah pengundi } \\
\text { berdaftar: } \\
11982\end{array}$ & $\begin{array}{l}\text { Che Abdul Rahim } \\
\text { (UMNO) } \\
\text { Che Abdullah Ahmad } \\
\text { (PAS) }\end{array}$ & $\begin{array}{l}4868 \\
2738\end{array}$ & 2130 \\
\hline
\end{tabular}

Sumber: Mohd. Zain Salleh, Sejarah UMNO Kelantan, Jawatankuasa Penerangan Perhubungan UMNO Negeri Kelantan, 1985, hlm. 222.

Calon-calon PAS yang bertanding dalam pilihan raya ini dengan menggunakan simbol 'Tapak Tangan Dengan Lima Batang Jarinya' ${ }^{84}$ yang melambangkan lima Rukun Islam, manakala lambang parti yang digunakan UMNO pula adalah 'Kapal Layar'. Setiap parti yang bertanding mengeluarkan manifesto masing-masing untuk menghadapi pilihan raya pra-kemerdekaan ini. Manifesto yang dihasilkan adalah berlandaskan prinsip dan dasar perjuangan parti masing-masing. Walaupun UMNO Pusat telah mengemukakan satu manifesto untuk digunakan UMNO seluruh Tanah Melayu, namun satu manifesto khusus untuk Kelantan juga telah dikemukakakan. Manifesto UMNO Pusat merangkumi 15 perkara, iaitu pentadbiran, tanam-tanaman, kewangan dan ekonomi, pelajaran, darurat, perikanan, perumahan, jabatan perkhidmatan penerangan, buruh, tanah, pemerintah tempatan, perubatan dan kesihatan, politik, perkhidmatan kebajikan masyarakat dan merancang bandar serta kawasan luar bandar. ${ }^{85}$

Penyertaan PAS dalam pilihan raya tersebut bukanlah merupakan suatu saingan yang mencabar. Penyertaannya dalam pilihan raya turut berhasrat mempercepatkan kemerdekaan, selain memperoleh pengalaman serta memperkenalkan parti itu kepada orang ramai. ${ }^{86}$ Sebagai sebuah parti yang memperjuangkan ideologi Islam, PAS berharap dapat menjadikan negara ini sebuah negara Islam. Dalam pilihan raya tahun 1955 di Pasir Mas, hanya UMNO yang giat menjalankan kempen, sementara PAS yang baru sahaja bertapak di 
Pasir Mas, perjalanan kempennya masih perlahan dan kurang berkesan dalam mempengaruhi rakyat untuk menyokong mereka. ${ }^{87}$

Isu yang menjadi bahan kempen utama UMNO Pasir Mas adalah isu kemerdekaan yang merupakan isu yang turut mewarnai kempen pilihan raya di seluruh Tanah Melayu ketika itu. Tidak sukar untuk UMNO memenangi hati penduduk Pasir Mas kerana perjuangan menuntut kemerdekaan inilah yang telah menyatukan orang Melayu sebelum ini sehingga tertubuhnya UMNO. Boleh dikatakan dalam menghadapi Pilihan Raya 1955 ini, tiada isu hangat yang dikemukakan oleh mana-mana parti bagi mewujudkan perasaan marah dan tidak berpuas hati dalam kalangan parti yang bertanding. ${ }^{88}$

UMNO dan PAS Pasir Mas seolah-olah memperjuangkan isu yang sama dalam kempen mereka, iaitu menuntut kemerdekaan. Menariknya PAS juga dilihat seolah-olah menyokong perjuangan UMNO untuk menuntut kemerdekaan Tanah Melayu dalam kempen pilihan raya yang diadakan. PAS tidak memberi tentangan atas usaha yang dilakukan oleh UMNO untuk mendapatkan kemerdekaan bagi Tanah Melayu, malahan turut menyokong rundingan pemimpinpemimpin UMNO seperti Tunku Abdul Rahman dengan pihak British mengenai isu kemerdekaan. Perkara yang tidak dipersetujui oleh PAS adalah cara pengisian kemerdekaan yang dilakukan. Ini termasuklah dengan bergabung bersama orang Cina dan menerima syarat-syarat yang dikemukakan oleh Inggeris dan Tanah Melayu perlu membentuk perlembagaan mengikut perlembagaan Britain. Hakikat ini tidak dipersetujui oleh PAS yang mahukan perlembagaan Tanah Melayu dibentuk berdasarkan prinsip-prinsip Islam dan menjamin hak-hak orang Melayu. ${ }^{89}$

\section{Kesimpulan}

Kelantan merupakan sebuah negeri yang unik jika dilihat dari segi budaya berpolitik rakyatnya yang mempunyai sedikit kelainan dengan penduduk di negeri-negeri lain. Tidak dapat dinafikan bahawa penduduk Pasir Mas amat meminati politik dan mengikuti perkembangannya secara dekat. Masyarakat tani Pasir Mas amat peka kepada hal-hal yang mengganggu keselesaan hidup mereka dan sentiasa berwaspada terhadap sebarang bentuk penindasan dan pemerasan oleh pihak luar. Dari segi politik rakyat Kelantan amnya dan Pasir Mas khususnya juga agak peka dengan perkembangan politik antarabangsa. Mereka turut bersimpati dengan keperitan hidup yang dirasai saudara seagama yang tinggal di luar lingkungan mereka. Penduduk Pasir Mas juga umumnya adalah rajin bekerja dan suka bantu-membantu serta amat menghormati sesiapa sahaja yang jujur dan tinggi akhlaknya 
Kesedaran berpolitik penduduk Pasir Mas adalah seiringan dengan kesedaran yang timbul dalam kalangan penduduk di negeri-negeri lain. Penolakan terhadap Malayan Union membawa kepada pemuafakatan orang Melayu yang dimanifestasikan dengan penubuhan UMNO dan juga PAS. Sejarah penubuhannya, UMNO dan PAS membawa orientasi dan pendekatan yang berbeza kerana kedua-dua parti tersebut mempunyai dasar dan perjuangan yang berbeza. Orientasi UMNO adalah bersifat kebangsaan, manakala PAS bersifat Islamik. Walaupun berbeza pendekatan, namun kedua-duanya berkembang dan mendapat sambutan penduduk Pasir Mas. PAS yang dilahirkan lewat sedikit daripada UMNO terus berkembang kukuh di Pasir Mas kerana kawasan ini terkenal dengan kehadiran sekolah pondok yang wujud dengan banyaknya. Pendekatan PAS yang bersifat Islamik dilihat lebih mudah diterima penduduk Pasir Mas yang mementingkan agama dalam kehidupan seharian.

Pada dasarnya pilihan raya pra kemerdekaan di Pasir Mas, Kelantan menunjukkan sokongan yang begitu padu dan menyeluruh kepada UMNO dengan sokongan melebihi 70 peratus. Perjuangan kemerdekaan yang dibawa UMNO adalah seiring dengan semangat inginkan kebebasan yang begitu tinggi dalam kalangan penduduk Pasir Mas. Ini memudahkan UMNO mendapat kepercayaan penduduk yang yakin dengan perjuangannya. PAS yang baru sahaja ditubuhkan dengan rasmi menjelang Pilihan Raya 1955 telah menjadikan medan pilihan raya tersebut sebagai platform untuk memperkenalkan dasar yang diperjuangkan mereka kepada orang ramai. Kekalahan PAS dalam pilihan raya tersebut sememangnya telah dijangka sejak awal dan tidak pula mematahkan semangat mereka untuk terus bersaing dalam pilihan raya berikutnya pada tahun 1959 .

\section{Nota}

$1 \quad$ Ab. Hamid Bin Othman, Intelijensia Melayu di dalam Beberapa Kegiatan Sosial di Kota Bharu Tahun-Tahun 1920-an hingga 1945, Tesis Sarjana Muda, Universiti Malaya, 1972, hlm. 25-30.

2 Saad Shukri Bin Haji Muda, Detik-Detik Sejarah Kelantan, Kelantan: Pustaka Aman Press, 1971. hlm. 40.

Ibid., hlm. 54.

Abu Bakar Hamid. "Mengenang Allahyarham Saad Shukri", Dewan Sastera, Mac 1971, hlm. 34-35.

Warta Malaya, 3 November 1938.

Al-Hikmah, 27 April 1939, hlm. 24-27.

Clive S. Kessler. "Muslim Identity and Politics Behavior in Kelantan" dlm. Roff, W.R (pynt). Kelantan: Religion, Society and Politics in a Malay State", Kuala Lumpur : Oxford University Press, 1974, hlm. 66. 
Wan Harun Haji Wan Yaacob. Sejarah Pembangunan Ekonomi Negeri Kelantan Semasa Pemerintahan PAS: 1959-1973, Tesis Sarjana Muda, Universiti Kebangsaan Malaysia, 1985/1986, hlm. 31.

$10 \quad$ Warta Malaya, 4 September 1940.

11 Clive S. Kessler. Muslim Identity and Politics Behavior in Kelantan, hlm. 82.

12 Al-Hikmah, 19 Disember 1940.

13 Majlis, 12 Januari 1946.

14 Ibid., hlm. 82-90.

15 Mohd Zain Saleh, Sejarah UMNO Kelantan, Jawatan kuasa Penerangan Perhubungan UMNO Negeri Kelantan, 1985, hlm. 5. Ab. Hamid bin Othman, Intelijensia Melayu, hlm. 71.

Ibid., hlm. 74 .

Ibid., hlm. 77.

Ibid., hlm. 80.

Ibid., hlm. 95.

Alias Muahmmad. Intelenjensia Melayu Kelantan, Kota Bharu: Mohd. Nawi Book Store, 1977, hlm. 79.

Ibid., hlm. 85.

Mohd. Zain Salleh. Sejarah UMNO Kelantan, hlm. 5 - 6.

Mohd. Asri Haji Muda, Memoir Politik Asri Meniti Arus, Bangi: Penerbitan Universiti Kebangsaan Malaysia, 1993, hlm.32.

Majlis, 6 Februari 1946.

Majlis, 19 Februari 1946.

The Straits Times, 1 Mei 1946.

Raja-raja Melayu telah mengadakan perbincangan pada 1 Mei 1946 berkaitan pelawaan Gabenor British iaitu Sir Edward Gent yang mahu berjumpa dengan mereka untuk membincangkan mengenai Malayan Union.

Muhd. Yusof Ibrahim. Ilmu Sejarah: Falsafah, Pengertian dan Kaedah, Kuala Lumpur : Dewan Bahasa dan Pustaka, 1997, hlm. 56.

Ramli Bin Isa, Sejarah Perkembangan Politik dan Pilihanraya di Kelantan 1955-1959, Tesis Sarjana Muda, Universiti Sains Malaysia 1988/89, hlm. 35-40.

Ibid., hlm. 55-60.

Mohd Zain Saleh. Sejarah UMNO Kelantan, hlm. 20.

The Star 13 August 2007, hlm. 17-18.

A.ZHachew C.M, “UMNO Kelantan: Penubuhan dan Perkembangannya”, Mastika, 1977, hlm.60.

Ibid., hlm. 35-45.

Marwan Saliman. "UMNO 1948 - 1955", hlm. 26-35.

Samad Idris. 25 Tahun Merdeka, Kuala Lumpur : Penerbitan Pustaka Budiman, 1992, hlm. 91.

Mohd Zain Saleh. Sejarah UMNO Kelantan, hlm. 34-35.

Ibid., hlm. 34-35. 
Keterangan lanjut tentang keahlian UMNO Pasir Mas pada awal penubuhannya, lihat Ramli Bin Isa,Sejarah Perkembangan Politik dan Pilihanraya, hlm. 34-37.

41 Keterangan Ustaz Hj Hassan Bin Che Soh AJK UMNO Bahagian Pasir Mas, di Pasir Mas 27.11.2012.

42 A.Z Hachew C.M. "UMNO Kelantan: Penubuhan dan Perkembangannya”, Mastika, 1977, hlm. 27.

43 Mohamed Agus Yusoff, Perkembangan dan Perubahan Sosio-Politik Kelantan 1955-1995, Bangi: Penerbitan Universiti Kebangsaan Malaysia,1995, hlm. 111.

$44 \quad$ Keterangan Ustaz Hj Hassan Bin Che Soh Pasir Mas 27.11.2012

$45 \quad$ Ibid., hlm. 121.

$46 \quad$ Mingguan Pedoman, 29 September 1959, hlm. 27.

$47 \quad$ Saad Shukri Bin Hj Muda. Detik-detik Sejarah Kelantan. hlm. 34-50. Lihat juga Yahya Bin Ismail, Bulan Purnama Di Kelantan. hlm. 45-60. Paridah Ali. "Sejarah PAS Kelantan 1953-1959", Malaysian Journal of History, Politics and Strategies Studies (JEBAT), 1973/1974, hlm.71-87. Ibid., hlm. 80 . Ibid., hlm. 48 .

Loteri ini mengambil konsep kelab lumba kuda yang terdapat di seluruh Tanah Melayu pada waktu itu dan dihukumnya haram dalam Islam. Loteri kebajikan UMNO diwujudkan pada tahun 1951. Utusan Melayu pada 19 ogos 1951, melaporkan tentang fatwa yang dikeluarkan oleh Mufti Pulau Pinang, Tuan Haji Abdullah Fahim bahawa judi loteri yang disokong UMNO adalah haram. Walaupun difatwakan haram, namun sehingga tahun 1953 loteri tetap dijadikan sumber ekonomi UMNO. Abdullah Fahim adalah datuk kepada Mantan Perdana Menteri Malaysia Datuk Sri Abdullah Ahmad Badawi. Persidangan khas Alim Ulama Pulau Pinang dan Seberang Prai di Madrasah Al-Khairiyyah, Pokok Sena,Seberang Prai memutuskan judi adalah haram bagi semua umat Islam. Kira-kira 50 orang alim ulama hadir dalam persidangan tersebut. Utusan Melayu, 29 November 1951, hlm. 24.

54 Paridah Ali."Sejarah PAS Kelantan", hlm. 83-87.

55 N.J Funston. Malay Politics in Malaysia 1945- 1969, hlm. 173.

56 Alias Muhammad. PAS Platform: Development and Change 1951 - 1986, Petaling Jaya: Gateway Publisihing House, 1994, hlm. 23-45.

57 Mohd. Asri Hj. Muda. Memoir Politik Asri, hlm. 47.

58 PAS Kelantan, Sejarah 50 tahun PAS Kelantan, Kelantan: Penerbitan PAS, 2001, hlm. 2.

$59 \quad$ Ibid., hlm. 39.

60 Anbalakan Kaisalam. Individu Dalan Sejarah, Alam Pensejarahan: Dari Pelbagai Perspektif, Kuala Lumpur: Dewan Bahasa Dan Pustaka, 1996, hlm. 56.

$61 \quad$ Ibid., hlm. 60.

62 Wan Shawaluddin Bin Wan Hassan. Biografi Amaluddin Bin Darus, Kertas projek, Jabatan Sejarah, Universiti Malaya, hlm. 4-5. Amaluddin Bin Darus di lahirkan di Kulim, Kedah pada 25 Disember 1927. Beliau adalah 
anak kepada pasangan Darus Bin Hassan iaitu berketurunan Benggala, India dan Aminah Binti Ahmad seorang berketurunan Mandailing-Patani. Mula mendapat pendidikan di Sekolah Melayu Kulim ketika berumur enam tahun, dan ke Sekolah Arab AL-Huda, Pulau Pinang ketika berumur 12 tahun. Pasca Perang Dunia Kedua, Amaluddin Bin Darus menyertai pasukan Bomba dan di tempatkan di Pasir Mas, Kelantan. Setelah 11 tahun berkhidmat beliau terpaksa menamatkan perkhidmatannya, setelah terlibat dengan satu kemalangan semasa bertugas iaitu kakinya terkena paku, ketika beliau memadamkan kebakaran.

63 Paridah Ali, "Sejarah PAS Kelantan”, hlm. 67.

64 Ibid., hlm. 74.

$65 \quad$ Ibid., hlm. 27.

$66 \quad$ Ibid., hlm. 37.

67 The Straits Times, 15 Ogos 1953, hlm.5. National Convention yang diadakan pada 14 Ogos 1953 di Johor dihadiri sembilan buah badan dan parti politik. Pertemuan untuk membincangkan kemerdekaan Malaya dan masa depan orang Melayu ini dianggap sebagai bersejarah kerana berjaya mengumpulkan begitu banyak badan-badan politik Melayu. Namun demikian, tidak ada sebarang keputusan diambil dalam pertemuan itu kerana cadangan yang dikemukakan parti-parti akan dibincangkan semula oleh UMNO dan Malayan Chinese Association (MCA) yang dijangka diadakan pada 18 Ogos 1953. Dalam National Convention ini, Tunku Abdul Rahman telah menggesa orang Melayu bersatu dan berusaha dan tidak menganggap diri sendiri sebagai 'lembu' yang boleh dibuli oleh orang lain. Tunku menyatakan orang Melayu perlu sedar bahawa mereka mempunyai kuasa dan hak untuk mentadbir negara sendiri. Tunku turut menggesa pemimpin-pemimpin supaya melenyapkan pendapat bahawa tanpa pertolongan British, orang Melayu akan menjadi hamba di negara sendiri. Dalam convention ini juga, sesetengah delegasi dengan lantang mengkritik UMNO kerana gagal berunding dengan badan-badan Melayu yang lain sebelum membuat ikatan dengan MCA dalam soal kemerdekaan. Delegasi ini mencadangkan tahun 1957 dipilih sebagai sasaran untuk mencapai kemerdekaan penuh dan pilihan raya kebangsaan diadakan pada tahun 1954 sebagai langkah pertama mencapai kemerdekaan. Delegasi ini juga turut mengkritik cadangan UMNO supaya Malaya terus berada dalam penguasaan Komanwel sesudah merdeka. Wakil dari Kelantan pula mencadangkan agar sultan-sultan dijemput sama dalam perbincangan kemerdekaan.

Terdapat beberapa pendapat yang menyatakan PAS menyertai Pilihan Raya Persekutuan yang pertama pada 27 Julai 1955 dengan harapan untuk mempercepatkan proses menuntut kemerdekaan Tanah Melayu yang sedang diperjuangkan UMNO. Hasil usaha PAS bersama Nasional Convention 1954, British bersetuju supaya pilihan raya diadakan pada 27 Julai 1955 iaitu satu tarikh di antara 1954 yang dicadangkan oleh Nasional Convention. 
Haji Ahmad Fuad mencadangkan supaya PAS menyertai National Conference manakala Mohd. Asri pula mencadangkan supaya PAS menyertai National Convention tajaan UMNO.

Mohd. Asri Hj. Muda. Memoir Asri, hlm. 22.

Paridah Ali. "Sejarah PAS Kelantan", hlm. 74.

Penyata Tahunan PAS Cawangan Kota Bharu 1955 /1956.

Mohd. Asri Hj. Muda. Memoir Asri, hlm. 52.

Suara Islam, Mac 1958.

Utusan Melayu Februari 1959.

Paridah Ali. "Sejarah PAS Kelantan", hlm. 87.

The Straits Times, 8 Mei 1951. hlm. 5.

78 Chamil Wariya. Siapa Kuasai UMNO, Kuala Lumpur: Media Intelek Sdn. Bhd., 1985, hlm. 21-30.

Penerangan lanjut mengenai kaedah ini boleh dirujuk dalam Dr. Yusuf Al-Qardhawi, Fi Figh Awlawiyat Dirasah Jadidah Fi Dhau' Al-Quran Wa As-Sunnah, hlm. 28 - 30.

Mohd. Asri Hj. Muda. Memoir Politik Asri, hlm. 50.

The Straits Times, 16 Jun 1955.

Mohd. Asri Hj. Muda. Memoir Politik Asri, hlm. 49.

Mohd Zain Salleh, Sejarah UMNO Kelantan, hlm. 220.

Hj Mohd. Amin Yaakub. Sejarah pemerintahan PAS Kelantan 1959-1990, hlm. 11.

Warta Negara, 16 Julai 1955.

Paridah Ali. Sejarah PAS di Kelantan 1953-1959, hlm. 79.

Mohamad Ali Mohamed. Sejarah Perkembangan Perjuangan UMNO Kelantan 1955-1959, Tesis Sarjana Muda, Universiti Kebangsaan Malaysia, 1977, hlm. 65.

$88 \quad$ Ibid., hlm. 75-77.

89 Ustaz Ismail Noh bekas Ahli Parlimen Pasir Mas 2004-2008. Dalam pilihan raya 2008 beliau menyerahkan kawasan yang dimenangi kepada calon bebas Dato' Ibrahim Ali. Ustaz Ismail Noh merupakan Yang Dipertua PAS Kawasan Pasir Mas. Temuramah dengan Ustaz Ismail Noh di rumahnya di Maahad Darul Quran, Slow Machang, Pasir Mas pada 23.12. 2012. 